\title{
To Investigate ESL Students' Instrumental and Integrative Motivation towards English Language Learning in a Chinese School in Penang: Case Study
}

\author{
Yee Chee Hong ${ }^{1} \&$ Malini Ganapathy ${ }^{2}$ \\ ${ }^{1}$ Wawasan Open University, Malaysia \\ ${ }^{2}$ School of Languages, Literacies and Translation, Universiti Sains Malaysia \\ Correspondence: Malini Ganapathy, School of Languages, Literacies and Translation, Universiti Sains Malaysia. \\ E-mail: malinik@usm.my
}

Received: July 4, 2017 Accepted: July 31, 2017 Online Published: August 2, 2017

doi: 10.5539/elt.v10n9p17 URL: http://doi.org/10.5539/elt.v10n9p17

\begin{abstract}
Malaysians have long realised the importance of being competent in English as one of the success factors in attaining their future goals. However, English is taught as a second language in Malaysia, and it is not easy to teach under such a foreign context, because authentic input may not exist beyond the classroom, especially in Chinese private schools. In this scenario, English is learnt as a subject with 10 sessions per week, which is considered insufficient for students to master the language effectively. Past research highlights the significance of motivation in English language acquisition. Motivated students tend to put in more effort in their academic endeavours by showing more persistence in their learning process. The purpose of the study was to identify and analyse whether instrumental or integrative motivation plays a more important role in promoting Form Four ESL students' English language learning. Furthermore, examine the areas of problems that affect ESL students' motivation towards English language learning. This study was a qualitative case study that used focus group interviews to elicit data from 12 students in a secondary school in Penang. The findings of this research indicate that students are more instrumentally motivated than integratively motivated in ESL learning. Instrumental motivation is found to have a greater impact on students' English language learning. This research also highlights that vocabulary and grammar are the biggest areas of problems that are encountered by students during their ESL learning process, which further influence their speaking and writing skills.
\end{abstract}

Keywords: integrative motivation, instrumental motivation, English language learning, Chinese school, ESL Students

\section{Introduction}

English is a global language (David, 2003) that is used internationally for cooperation and communication. It is also the second official language in Malaysia other than Bahasa Malaysia. Malaysians have realised the importance of being competent in English as one of the success factors in their future goals or carrier. Moreover, students can improve their English competency through motivation, which include integrative and instrumental motivation (Thang, 2004). The term motivation is derived from the Latin word "movere", which carries the meaning "to move". Some scholars (Huitt, 2001; Kleinginna, 1981) defined it as the factor that energises and provides direction to certain behaviors. It also give explanations to why people do something, how long they will do it and how much effort they will put in to pursue a goal.

Motivation plays a significant role in language learning success (Gardner, 1985), especially where English is taught as a second language in Malaysia. It is difficult for students to master the language, as authentic language input may not exist beyond the classroom. Under such circumstances, the learning motivation of student is particularly important towards the mastering of English language. The relationship between learning and motivation is inseparable, motivation can promote learning and learning can produce motivation again (Ausubel, 1968).

On the basic of such inference, students' motivation towards English language learning might, in some degree, determine or influence their learning results. Learner's enthusiasm, commitment and persistence are the key factors that decide the success or failure of language learning (Dornyei, 2002). Students with strong motivation 
often obtain excellent achievement, while students without motivation are those who always give up easily and this could be due to the factor that motivated students are more eager and willing to devote their time to language learning.

Since motivation is an indispensable factor in second language acquisition, many studies had been carried out in this domain (Lei, 2012; Chunmei, 2013; Zhigang, 1993). Some of these studies encompass various levels of motivation, types of motivation, factors that affect motivation and other related variables. By understanding the psychological theory and process in motivating students learning thoroughly, only then, a teacher or educator can stimulate students' motivation, encourage and enhance students' English learning. Hence, this study focused on providing information for determining the extent and types of motivation, such as integrative or instrumental, in English language learning.

\subsection{Background of the Study}

Malaysia is a former British colony and English language has been used long before her independence. English became more important when the government of Malaysia had planned to develop the country into a fully industrialised nation by the year 2020. However, English has always been taught as a second language in Malaysia's education system, under the supervision of the Ministry of Education. Bahasa Malaysia is the main medium used in the primary and secondary school curriculum (both national and national-type schools), where English language can only be learnt through the English subject. The same goes to Chinese private schools, where Chinese language is the main medium in all the teaching instruction and curriculum, except the language class of Bahasa Malaysia and English. Students in these schools learn Bahasa Malaysia and English language as a subject (Saran, 2005).

An English teacher from a Chinese private school in Penang pointed out that students study English language with a schedule of 10 sessions per week where two (2) sessions are allocated daily with a duration of thirty five (35) minutes for each. Other than that, students are not exposed to the English language which means that a student only learns English language for 1 hour and 10 minutes per day. It was also highlighted that teachers are given the prerogative to use Mandarin to explain certain vocabularies or hold discussions during the class. As a result, some of the students do not fully understand when the teacher elaborates in English.

Thus, after a comparatively short duration of English lessons, students have to strengthen their learning at home, otherwise, they might have difficulties in mastering the language effectively, and their eagerness of using English in class might also be lacking. As such, it is important to determine the types of motivation that can promote Form Four Chinese students learning of English and the challenges that they are confronted with in daily classes. In Malaysia, the Form 4 level is also known as the $10^{\text {th }}$ grade in other countries such as Australia, Canada and United States. The students at this level are 16 years old, and it is their fourth year in their secondary school.

\subsection{Objectives of the Study}

The aim of this study was to identify and analyse whether instrumental or integrative motivation plays a more important role in promoting Form four ESL students towards English language learning. Furthermore, to examine the areas of problems that affect ESL students' motivation toward English language learning.

\subsection{Research Questions}

This research study is conducted to investigate form four private Chinese school ESL students in Penang, with the objective of finding the answer for the following questions:

1) Are ESL students integratively or instrumentally motivated towards English language learning?

2) What are the areas of problems that affect ESL students' motivation towards English language learning?

\subsection{Significance of the Study}

The significance of this study was to gather information and outcomes that are beneficial to teachers or educators who teach at Chinese secondary schools, by highlighting to on the types of motivation and challenges faced by students towards English language learning. The findings will also assist teachers to make improvement in the teaching plans and instructions, thus designing more suitable approaches in teaching the English language. Furthermore, the findings of this study will be of significance to researchers, ESL/EFL teachers and learners, and course designers too. 


\subsection{Limitation of the Study}

This study may has some limitation. Firstly, it is a small scale case study that covers only Penang area, with all participants coming from the same secondary Chinese school. As such the results obtained could not be generalised, as the sample size selected could not exemplify the entire populations at large. Secondly, this study is also restricted to investigating students' instrumental and integrative motivation towards English language learning only, others variables like student's family background, number of language spoken, academic achievement and learning environments were not catered or accounted for in this study. Lastly, there may be possible biases in the data collection and interpretation, due to subjectivity and cultural background of the researcher. However, these study's findings will still be valuable to those English teachers teaching in Chinese secondary school context. It will give the teachers an idea about which types of motivation promote students the most in English language learning, as well as insight of motivation from students' perspective and challenges faced. With these findings, English teachers can improve their instructions, by incorporating these motivational factors into their teaching plans, and help the students in mastering English language more efficiently.

\section{Literature Review}

\subsection{Definitions of Motivation}

Motivation is a complicated psychological process that cannot be precisely defined. It is often related to an internal need and behavior that push people towards gaining their goals (Melendy, 2008). Based on this statement, it explains why some employees and children perform better and are more efficient in their jobs or homework, paying more attention and persistency, while others are not. This variable is also crucial in any learning process, including English language learning (Angelica, 2011). As such, how do we define the term "Motivation", so that we may have a clearer understanding?

Kea (2008) describes motivation as a result of conscious and unconscious factors that stimulate and energise people in continually doing something to attain a preset goal. Such factors can be viewed from the perspective of internal and external aspects like, intensity of desire, reward of achieving the goal and expectations from others.

Motivation is related to a person's behaviors that include decision making of doing something, duration of doing it and how much effort will they put in it (Dornyei, 2001). Some view it as an internal drive that stimulates a person to perform certain action. If we have a specific goal that we desire, feel worth of doing it and try hard to reach the goal, then we can define these endeavors as action driven by motivation (Harmer, 1991). Williams and Burden (1997) defined motivation as a particular condition of cognitive and emotion arousal, which relate to conscious decision making and action, sustainability of physical effort through a period of time towards a preset goal.

Motivation is a process that cannot be observed directly, but can be inferred by behaviors, such as effort, persistence and verbalisation. It involves goals that drive the direction and action, physical or mental activity that guide towards attaining goals. To put it in short, motivation is a process whereby goal-directed activity is sustained (Pintrich, 1996). There are two types of language learning motivation, which is instrumental motivation and integrative motivation (Gardner \& Lambert, 1972). Learners with an instrumental motivation want to learn a language because of a practical reason such as getting a job promotion or getting into university. Whereas, learners with integrative motivation want to learn the language so that they can better understand and get to know the people who speak that language.

\subsection{The Theory of Motivation}

Many theories regarding motivation have been developed throughout the years, such as Theory of Expectancy value, Theory of Achievement motivation, and Theory of Attribution. Weiner (1994) suggested the Theory of Social motivation; he believed that most of the human motivation comes from the social cultural context, instead of an individual. Another scholar, Covington (1998) proposed the Theory of Self-worth, which explains people are highly motivated to behave in ways to protect and secure their personal value and worth. They will try everything to save their own face. Atkinson and Rayor (1974) claimed that, achievement motivation is the result of expectancy for success and fear of failure, in their Theory of Achievement motivation.

Deci and Ryan (1985) describe in their Theory of Self-determination that, a person's motivation can be influenced or initiated by intrinsic and extrinsic factors, which they refer to, as self-determined and controlled forms of motivation. Behaviors that concern with experience of own satisfaction such as happiness and curiosity are classified as intrinsic motivation. On the contrary, extrinsic motivation involve behavior with the purpose of receiving extrinsic reward or to avoid punishment. Second language learners with instrumental motivation learn a language with a more utilitarian purpose, such as applying for a well-paid job or achieving higher social status. 
On the other hand, integrative motivation learners learn a second language propelled by their positive manners towards the target language group and desire to integrate into the target language community (Wong, 2011)

Gardner and Lambert's (1972) theory of motivation focused on two important motivational constructs; integrative and instrumental motivation. The purpose of the study was to discover the relationship between these two motivational constructs and second language learning success. The learners' attitude towards second language learning was measured and defined as integrative and instrumental motivation in a dichotomy model, and Gardner and Lambert discussed how they accounted for the learning proficiency. Gardner and Lambert's idea of integrative and instrumental motivation in relation to learning a second language has been widely accepted in the field of ESL studies.

\subsection{Conceptual Framework of the Study}

Figure 1 below shows the entire concept of this research, which focuses on instrumental and integrative motivation. Focus group discussion, with preset questions regarding these two types of motivation will be asked to participants. Ultimately, results or feedback of all participants will be compared and analysed for finding out which type of motivation is predominant in the second language learning process.

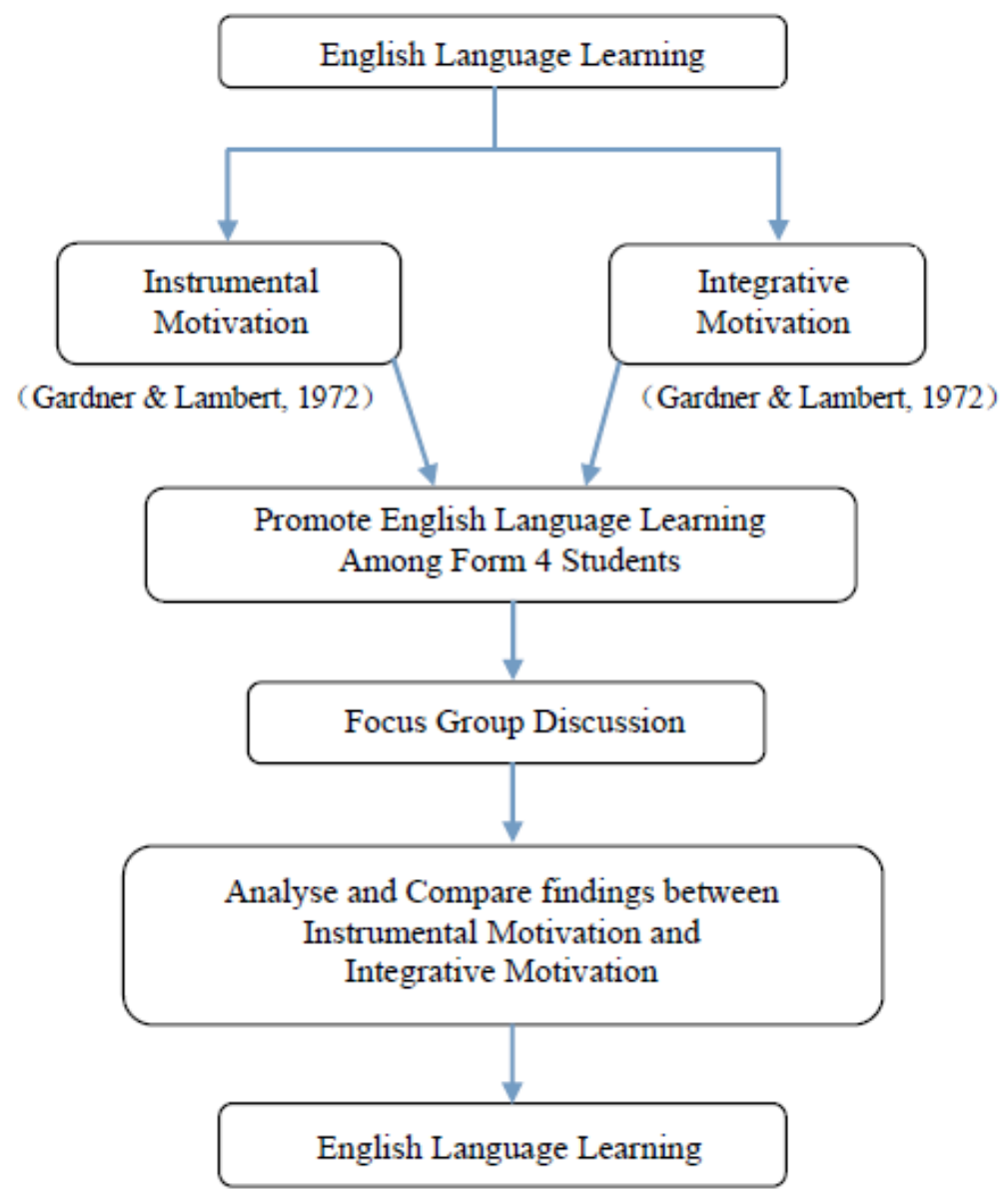

Figure 1. Conceptual framework of the research

\subsection{The importance of Motivation in Second Language Learning}

Oxford and Shearin (1994) mentioned that motivation is crucial to second language learning, because it provides the primary drives to initiate the learning process and persistency through mastering the language. Once the learning motivation is stimulated, students will enter into a stage of active learning, express positive attitude towards learning the language, and continue to focus their attention on mastering the knowledge.

Chunmei Long, Zhu Ming and Liping Chen (2013) also claimed that, it is difficult for anybody to achieve a 
long-term goal of language learning without motivation. Motivation and learning achievement are mutually connected; high motivation might lead to successful learning of the language and successful learning achievement conversely will promote high motivation in the learning process. In this vein, motivation plays an important role in second language acquisition, including English. It refers to an individual's desire to learn a specific language and students' positive attitudes toward learning it (Dornyei, 1994).

Since motivation is one of the stronger driving forces in language learning success, what might be the reasons or factors that give rise to it? According to Ely (1986), motivation is determined by a set of orientations and orientation represents different reasons for learning a language. Some of these orientations are learners' internal factors, such as interest or desire to succeed. External factors, include the context of learning, reward and peer pressure.

\subsection{Types of Motivation}

Gardner (1985) and Krashen (1988) categorised the learner's orientation or factors of motivation in second language learning into two types, which is integrative motivation and instrumental motivation. Both types of motivation affect the success of second language acquisition from different perspectives.

Integrative motivation as defined by Brown's (1994) is where learners have the desire to integrate into the target language community, culture and become part of that society. Learners learn the second language because they wish to socialise or participate in the target language group (Saville, 2006). Masgoret and Gardner (2003) classified integratively motivated learners as being open to other language communities, plus having positive and favorable attitudes throughout the learning process. Furthermore, integratively motivated learners tend to have more persistence in their learning, especially when they encounter challenges or difficult tasks. This is because they have internalised their motive of learning into their self-value system, which explain why integratively motivated learners put more effort into their learning and obtain greater achievements in second language acquisition (Wang, 2008).

Gardner et al. (1983) defined instrumental motivation as "Learning for perceived utility". Learners of such type learn another language with the purpose of some pragmatic gains, instead of social implication with the target language community (Gardner, 2010). These instrumental goals might increase the social status or self image, better careers and business opportunities, to further study or meet the requirements of school, reading technical materials or translation, etcetera (Saville, 2006). Instrumentally motivated learners perform mainly for the attainment of external rewards, such as appraisal, personal fulfillment, status or power. Hence, it can be considered that instrumentally motivated learners' desire to learn the second language is aligned to accomplish some non-interpersonal purposes.

Gardner (1985) suggested that integrative motivation supersedes instrumental motivation, because integrative motivation involves attitudinal factors and goal orientated behaviors, which are important to second language learning process.

However, Dornyei (2001) refuted that integrative and instrumental motivation are not on the opposite aspect, it is more like two sides of a coin. Both of them are positively related and contribute to the achievement of language learning. Wan-er (2008) also claimed that, when instrumental motivation and integrative motivation are used together in a language study, it creates more positive results for the learners.

\subsection{Related Research}

Zhao (2012) had conducted a study to investigate the basic motivation types of 124 Chinese students who were learning English as second language in a local college in China. The findings indicated that these students were more instrumentally motivated than integratively motivated. This was due to students' limited opportunities to communicate with the target native group or foreigners, which might be the reason why learning English through integrative motivation was difficult.

Zhao's findings were supported by Chunmei Long et al's (2013) study, which related to a case study on 45 junior-middle school students in Gejiu, China. Questionnaires were distributed to these students in order to investigate their learning motivation on English language. The results indicated that most of the students understood that, motivation is the key factor to get good grades in examinations; they also have a clear study motivation. Furthermore, most of the motivation was instrumental; however, students' learning motivation level towards English was not high.

Wang (1993) did an investigation in Hong Kong among 45 ESL students in order to find out factors that affect Chinese ESL learner's acquisition. When students were probed if they were integratively motivated in their language learning, only 9 of them gave a positive response while the rest were instrumental orientated. Most of 
them learn English with the purpose of obtaining good jobs in the future, to make more income or to improve their social status. However, Wang also found that those instrumentally motivated students could not commit their time and energy to their learning, and had the tendency to give up more easily or became frustrated when they were encountered with difficulties in their learning compared to integratively motivated students.

Muftah and Rafik-Galea (2013) also conducted a study regarding language learning motivation among Malaysian Pre-University students. 182 non-English major students were selected to fill a questionnaire reflecting their attitudes and motivation towards learning English. The findings indicated that the motivation level of these students was high and more instrumentally motivated but, their integrativeness was also high. The explanation to such phenomena might be, students were trying to preserve their identity, fearing that integrative motivation to the target language or community could negatively affect their own culture or language.

Wimolmas (2012) conducted a survey study to 30 first-year undergraduate students at an international institute in Thailand, by using Gardner's Attitude/Motivation Test Battery (AMTB). The results showed that students were highly motivated to learn English in both instrumental and integrative aspects. In fact, it had discovered that students were slightly more "instrumentally" motivated.

Kitjaroonchai and Kitjaroonchai (2012) in Thailand also carried out a study using Gardner's AMTB on 137 English major Thai students. It showed similar findings to the above research, which indicated high level of motivation in both integrative and instrumental aspects. Furthermore, the proportion of instrumental motivation was found slightly higher than the integrative motivation. The investigation also revealed that, both types of motivation contributed to students' academic achievement and the process of English language learning. From the above mention studies, we can notice that instrumental motivation was found to be more predominating than integrative motivation in ESL learning.

However, Engin (2009) conducted a study in Turkey, among a group of 44 students, regarding the types of motivation students need for learning a foreign language successfully. The results indicated that "integrative motivation" was more effective than "instrumental motivation" for second language learning success. This was because instrumental motivation focuses on a pragmatic approach, whereas integrative motivation relates to personal desire and persistency to achieve certain goals, especially in the tedious process of second language learning.

In view of all the literatures above, there is no consistent agreement or views on the superiority of one type of motivation over the other. This contradicts with the findings of Gardner and Lambert (1972) as it was claimed that integrative orientation is more superior to instrumental orientation in second language acquisition. However, there is a common point where both integrative and instrumental motivations are important factors to second language learning. The dominance of one type of motivation to another might vary among the subjects or contexts that are being investigated. Therefore, more research is required in this field to provide different perspective and reference point, so that a better understanding can be gained of student's instrumental and integrative motivation and levels of motivation towards English language learning.

Many researches and studies have been conducted regarding the influences of different type motivation towards ESL students learning. However, no research to date, have looked into the influence of both instrumental and integrative motivation among Form 4 students, in a Chinese private school in Penang. Thus, there is a need to carry out this study in order to identify which type of motivation promotes greater ESL learning among the Form 4 students.

\section{Research Methodology}

\subsection{Research Design and Procedures}

From the literature review above, many studies had been carried out to investigate the relationship between motivation and second language learning achievement. Most of the methods used in the research were quantitative in nature. This study used a qualitative method, specifically a case study in order to provide greater insights and deeper thoughts of the students, regarding motivation, from their point of view.

Focus group discussions were administered in this research. Three (3) focus group discussions at a selected Chinese school in the Penang region were conducted. Each group discussion consisted of four (4) participants. So, this adds up to a total of twelve (12) participants. Instead of doing only one (1) group, three (3) group discussions were conducted with the intention of validation and comparison of data for locating and finding any similar patterns, and points among these participants. The researcher had written to the principal of the selected school prior to the research. The purpose of the study was stated in the letter and the principal was reassured that all personal information of students, will be confidential. The consent of all participants was obtained. All focus 
group discussion sessions were conducted after school.

\subsection{The Samples}

The samples for this study consisted of twelve (12) participants who were aged 16 and were Form 4 students. Each group comprised of four (4) students who were selected randomly by their English teacher; two boys and two girls in a group. The selected subjects were from the same class, taught by the same English teacher, using the same textbooks or materials. The reason for this criteria is to minimise any uncertain factors that will interfere with the results of the study. It will also facilitate easier comparison while these students were considered to be of equal ability or from the same background and conditions. All participants were encouraged to communicate freely and honestly, as their personal data will be kept confidential, including the personal details of their English teacher and school.

\subsection{Research Instrument}

The research instrument used in this study is focus group discussions. It is an approach that encourages yielding information from a group of people in regards to their opinion and perceptions regarding a certain topic (Marshall, 2010). This method includes discussions related to the research questions. Feedback from the participants were recorded and analysed.

The instrument used in this study comprised of 12 open-ended questions. These questions were based on Ratanawalee Wimolmas's (2012) previous research, which was adapted from Gardner's Attitude / Motivation Test Battery, (AMI). The researcher adapted the questions to suit current study's needs. These questions were divided into three (3) main parts as follows (Appendix 1):

Part I: General information of students - gender and age, plus a general question.

Part II: Students motivation related to integrative or instrumental motivation types. Question numbers 1, 3,5,7,9 are instrumental motivational items, whereas question numbers 2, 4, 6, 8, 10 are integrative motivational items.

Part III: Students' perception of language learning difficulties or area of problems (writing, reading, listening and speaking, etc) which could affect their learning motivation.

These questions will be asked in bilingual, which is English and Chinese, due to some of the students in Chinese school might not correctly perceive the questions in English. The researcher will supervise closely to make sure that all the participants understood all the items clearly.

\subsection{Data Collection and Procedures}

Twelve (12) selected students from a Chinese school in Penang responded to twelve (12) pre-set questions in a format of focus group discussion. Explanation regarding the aim of this study was given to all the participants, which are, to find out the motivation types and areas of problems in English language learning. The researcher also emphasised on the privacy of this research; neither participants name nor the name of their school will be mentioned in the report of this research. However, they were informed too that at any point, they could stop their participation or choose not to answer any of the questions, if they felt uncomfortable or intimidated. The answer from all participants were recorded in notes accordingly. Consent from the school and parents had been obtained, no video or audio records are allowed as agreed with the principal.

Focus group discussion was chosen as data collection method for this study, because this technique saves a lot of time compared to the one to one interview. Furthermore, it prevents the possibility of gathering repetitive information, and participants can clarify their views or even raise a question to each other's responses, which will facilitate better insights.

\subsection{Data Analysis}

The Qualitative Data Analysis (QDA) was used to convert the qualitative data into some form of explanation or interpretation, by describing was found and then code them into themes (Taylor \& Gibbs, 2010). Seidel (1998) had developed a model to illustrate the process of qualitative data analysis, which is shown in the diagram below: 


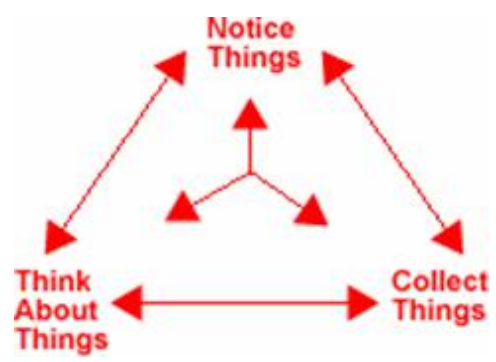

Figure 2. Qualitative data analysis process (Seidel, 1998)

There are three (3) main parts in this model, which is Noticing, Collecting and Thinking about things, they are interlinked and cyclical. While think about things, we might notice further things and collect them, just like solving a puzzle. In the process of QDA analysis, codes were assigned to the collected data according to topic or theme. This labeling will then act as sorting and collecting devices, enabling the researcher to quickly put together all the texts and data that are associated to specific themes or ideas. As such, the data was written down, organised and categorised according to different themes.

\section{Findings}

\subsection{Introduction}

Focus group discussions were used as the data collection method to examine ESL students' motivation towards English language learning. These discussions were conducted in a private Chinese school in Penang, which involved three (3) groups of 4 students, and it totaled up to twelve (12) students from the same class. Each discussion was conducted after school hours with the duration between 40 minutes to one hour, within the school premises for safety measurement. All feedback from the participants was being noted down by the researcher. Based on the agreement with the school principal, the identity of all participants (names, gender or ethnicity) would be kept confidential for ethical consideration. They were labeled by using alphabets and numbers to indicate their group number and sequence. For example, GD1-A refers to the first student in the first group discussion. These raw data were categorised into themes according to the grounded theory and enabled the researcher to find the answers to the research questions.

\subsection{Results of ESL Students' Motivation towards English Language Learning}

\subsubsection{Motivation Level of the Students towards Learning ESL}

In the focus group discussion, each group was asked eleven (11) semi - structured questions that related to two types of motivation, which were integrative and instrumental motivation respectively. The tables below indicate the feedbacks recorded from the participants. These data were analysed and compared according to their motivation types.

Table 1. General Q: Why do you learn English?

\begin{tabular}{|c|c|c|}
\hline No. & Responses of Participants & Type of Motivation \\
\hline GD1-A & $\begin{array}{l}\text { Because it is an international language, so it is important for us to learn } \\
\text { it. }\end{array}$ & Instrumental \\
\hline GD1-B & $\begin{array}{l}\text { Because it is use widely in Malaysia, I can get better job and pass the } \\
\text { interview. }\end{array}$ & Instrumental \\
\hline GD1-C & $\begin{array}{l}\text { My parent told me since childhood, learning English can have bright } \\
\text { future. }\end{array}$ & Instrumental \\
\hline GD1-D & Because it is important and I want my future better. & Instrumental \\
\hline GD2-A & $\begin{array}{l}\text { English is a beautiful language, it is quite easy to learn and I like it. I } \\
\text { can communicate and make friend from around the world. }\end{array}$ & Integrative \\
\hline GD2-B & $\begin{array}{l}\text { I want to study at university in the future and English is the main } \\
\text { medium use to communicate. }\end{array}$ & Instrumental \\
\hline GD2-C & Because it makes me look more knowledgeable and people will respect & Instrumental \\
\hline
\end{tabular}


me.

GD2-D I want to live in western country in the future, because I like their culture. I have some friend living there too.

Integrative

GD3-A like English because I always score high mark in this subject and Instrumental
make me feel more confident.

I like English because I always score high mark in this subject and Instrumental
make me feel more confident.

GD3-A like English because I always score high mark in this subject and Instrumental
make me feel more confident.

GD3-B Because English is a school subject, I will get scold by my parents if I fail the test.

Instrumental

GD3-C

Because English is a useful language that can be used all around the world.

Instrumental

GD3-D

Because I want to study overseas, they all speak English there, so I have to learn it.

Instrumental

From the above feedback, approximately $83 \%$ of the students were instrumentally motivated and only $17 \%$ were integratively motivated in learning English as second language.

Below are the results of semi - structured designed questions that were posted to the students during the focus group discussion. Questions 1, 3, 5, 7, 9 are instrumental motivational items, whereas question 2, 4, 6, 8, 10 are integrative motivational items.

Table 2. Q1: Do you think being proficient in English can lead to more success and achievements in life? Why? (Instrumental)

\begin{tabular}{lll}
\hline No. & Responses of Participants & Instrumental \\
\hline GD1-A & Yes, because I can have more option in finding job. & Affirmative \\
GD1-B & $\begin{array}{l}\text { Yes, because I can find job easily and communicate with foreigner } \\
\text { when go travel. }\end{array}$ & Affirmative \\
GD1-C & Yes, because it can help me graduate from the University. & Affirmative \\
GD1-D & Yes, because everybody speak English in big company, so it is & Affirmative \\
& important to our career. & \\
GD2-A & $\begin{array}{l}\text { Yes, it can help us in many ways, including communicating with people } \\
\text { in other country while on study or working. }\end{array}$ & Affirmative \\
GD2-B & $\begin{array}{l}\text { Yes, we can study and work in more develop country and have more } \\
\text { opportunity. }\end{array}$ & Affirmative \\
GD2-C & Yes, because we can find a better job. & Affirmative \\
GD2-D & Yes, because I can communicate with other country people & Affirmative \\
GD3-A & Yes, it will bring us more work opportunity. & Affirmative \\
GD3-B & Yes, because it is an international language, many things are related and \\
convey in English. & Affirmative
\end{tabular}

From the above feedback $100 \%$ of the students agreed that by mastering English language at a proficiency level, it will help them to be successful and achieve more in life. 
Table 3. Q2: Do you think learning English will help you to be an open minded and sociable person like native speakers? Why? (Integrative)

\begin{tabular}{|c|c|c|}
\hline No. & Responses of Participants & Integrative \\
\hline GD1-A & $\begin{array}{l}\text { Yes, I will be more confidence of myself and have courage to speak to } \\
\text { others. }\end{array}$ & Affirmative \\
\hline GD1-B & Maybe, it is up to that person, I think. & Negative \\
\hline GD1-C & Yes, because western people culture is more open minded than us. & Affirmative \\
\hline GD1-D & $\begin{array}{l}\text { No, it depends on the characteristic of that person, not the language he } \\
\text { speaks. }\end{array}$ & Negative \\
\hline GD2-A & $\begin{array}{l}\text { Yes, because I get to learn their point of view and be more expressive } \\
\text { like English speaking people. }\end{array}$ & Affirmative \\
\hline GD2-B & $\begin{array}{l}\text { No, because it is about your attitude and communication skills, have } \\
\text { nothing to do with learning English. }\end{array}$ & Negative \\
\hline GD2-C & $\begin{array}{l}\text { No, because we are in Malaysia, we do not have the environment of } \\
\text { western country. }\end{array}$ & Negative \\
\hline GD2-D & $\begin{array}{l}\text { Yes, because I can make friend from all over the world through internet } \\
\text { and learn their culture. }\end{array}$ & Affirmative \\
\hline GD3-A & $\begin{array}{l}\text { No, because I seldom have the opportunity to chat with any foreigner or } \\
\text { people that speak English. }\end{array}$ & Negative \\
\hline GD3-B & $\begin{array}{l}\text { No, it is the way they are being educated, not like the way in our country, } \\
\text { so is not about the language. }\end{array}$ & Negative \\
\hline GD3-C & $\begin{array}{l}\text { No, I don't think so. Does this mean if a foreigner learn Chinese, then he } \\
\text { will become more conservative? }\end{array}$ & Negative \\
\hline GD3-D & No, because it is about your knowledge and how many people you meet. & Negative \\
\hline
\end{tabular}

Table 3 highlighted that a smaller proportion of approximately $30 \%$ of the students agree that learning English will make them more open minded and sociable, while the other $70 \%$ disagreed. Some of the students conveyed that it was about individual personality, attitude, the environment they live in and the education they received but it had nothing to do with the language.

Table 4. Q3: Do you think learning English will make you knowledgeable and skillful ? Why? (Instrumental)

\begin{tabular}{|c|c|c|}
\hline No. & Responses of Participants & Instrumental \\
\hline GD1-A & Yes, because I can read all the skill that only available in English. & Affirmative \\
\hline GD1-B & $\begin{array}{l}\text { Yes, I can watch English news and Youtube video that Asia channel do } \\
\text { not have. }\end{array}$ & Affirmative \\
\hline GD1-C & $\begin{array}{l}\text { Yes, because I can read more knowledge about something in the } \\
\text { internet, where most of them are written in English. }\end{array}$ & Affirmative \\
\hline GD1-D & No, I think it is the attitude, not language. & Negative \\
\hline GD2-A & $\begin{array}{l}\text { No, you become knowledgeable if you learn a lot and skillful if you } \\
\text { practice more, not by just learning a language. }\end{array}$ & Negative \\
\hline GD2-B & $\begin{array}{l}\text { Yes, I can ask people from other country about their latest technology } \\
\text { and knowledge or problem I cannot solve. }\end{array}$ & Affirmative \\
\hline GD2-C & Yes, because I can communicate with them easily. & Affirmative \\
\hline GD2-D & Yes, because it will help me in my study and work in future. & Affirmative \\
\hline GD3-A & $\begin{array}{l}\text { No, you will have to be willing to learn and practice to become } \\
\text { knowledgeable and skillful. }\end{array}$ & Negative \\
\hline
\end{tabular}




\begin{tabular}{|c|c|c|}
\hline GD3-B & $\begin{array}{l}\text { Yes, because we can find many source or latest research report on the } \\
\text { internet which is written in English only. }\end{array}$ & Affirmative \\
\hline GD3-C & $\begin{array}{l}\text { Yes, because many books regarding advance technology and methods } \\
\text { are written in English. }\end{array}$ & Affirmative \\
\hline GD3-D & $\begin{array}{l}\text { Yes, you can read a lot more other than Chinese books, which will } \\
\text { widen our point of view, become knowledgeable. }\end{array}$ & Affirmative \\
\hline
\end{tabular}

$75 \%$ of the students agreed that learning English will make them more knowledgeable and skillful, because they can read more and obtain resources that are only available in English. Meanwhile the other $25 \%$ disagreed as they think that it is about one's attitude and how much one reads or practices the language.

Table 5. Q4: Do you think learning English will enable you to appreciate English arts and literature? Why? (Integrative)

\begin{tabular}{|c|c|c|}
\hline No. & Responses of Participants & Integrative \\
\hline GD1-A & Yes, because we can understand English more deeply. & Affirmative \\
\hline GD1-B & $\begin{array}{l}\text { Yes, I think can, because we can learn about their history and culture or } \\
\text { resources. }\end{array}$ & Affirmative \\
\hline GD1-C & Maybe, I am not sure, because I am not use to English literature. & Negative \\
\hline GD1-D & $\begin{array}{l}\text { No, I just want to learn the language, no interest in the literature, } \\
\text { sometime it is boring. }\end{array}$ & Negative \\
\hline GD2-A & $\begin{array}{l}\text { Yes, because I can learn more vocabulary or difficult word that is used } \\
\text { in the literature. }\end{array}$ & Affirmative \\
\hline GD2-B & No, because I have no interest in it, difficult to understand. & Negative \\
\hline GD2-C & No, I study it just to pass the subject. & Negative \\
\hline GD2-D & Yes, I love reading English story or novel. & Affirmative \\
\hline GD3-A & $\begin{array}{l}\text { No, I don't like English literature, because I don't understand what it is } \\
\text { talking about. }\end{array}$ & Negative \\
\hline GD3-B & No, I am Chinese, I don't like western culture. & Negative \\
\hline GD3-C & $\begin{array}{l}\text { No, I didn't see any relation between learning English and appreciate } \\
\text { English literature and arts. }\end{array}$ & Negative \\
\hline GD3-D & No, because I always get low mark at the literature part, I don't like it. & Negative \\
\hline
\end{tabular}

From the above feedback, only approximately $30 \%$ of the students agreed that learning English will enable them to appreciate English arts and literature, by understanding English history and culture. Furthermore, improve their vocabulary. On the other hand, 70\% of students disagreed, because they think English literature is difficult, boring and basically, lack interest.

Table 6. Q5: Do you think learning English will make other people respect you? Why? (Instrumental)

\begin{tabular}{lll}
\hline No. & Responses of Participants & Instrumental \\
\hline GD1-A & Yes, people will think you are more educated. & Affirmative \\
GD1-B & No, some who don’t know English also respected by others. & Negative \\
GD1-C & Yes, it makes you look more knowledgeable. & Affirmative \\
GD1-D & No, everyone can learn English, nothing special. & Negative \\
GD2-A & $\begin{array}{l}\text { No, people respect you because of your behavior and attitude, not } \\
\text { because you know English. }\end{array}$ & Negative \\
GD2-B & No, this has nothing to do with learning English, we must respect others & Negative \\
\hline
\end{tabular}


first if we want to gain their respect.

GD2-C Yes, because you know one more language that others might not know or efficient in.

Affirmative

No, if a person who speak good English but have bad moral, people will also not respect him.

Negative

GD2-D

Yes, cause many official speeches are delivered in English, if can't

GD3-A speak in English; others might look down on you.

Affirmative

GD3-B Yes, people who speak English sound more knowledgeable and more educated.

Affirmative

No, I think learning English and make other people respect you is two different matters.

Negative

GD3-C

No, because we respect people of his/her good characteristic, not

GD3-D because of what language he/her spoken.

Negative

From the findings from Table 6, approximately $42 \%$ of the students agreed that learning English will earn respect from others, because it makes them sound more knowledgeable and educated. While the other $58 \%$ of the students disagreed, because they think respect is earned by good behavior and personal characteristics and not by learning a language.

Table 7. Q6: Do you think learning English will enable you to participate freely in academic, social, and professional activities among other cultural groups? Why? (Integrative)

\begin{tabular}{|c|c|c|}
\hline No. & Responses of Participants & Integrative \\
\hline GD1-A & $\begin{array}{l}\text { Yes, because English is international language, we can use it to } \\
\text { communicate with other country people. }\end{array}$ & Affirmative \\
\hline GD1-B & $\begin{array}{l}\text { Yes, because you can understand what other people said and express } \\
\text { our thought and ideas. }\end{array}$ & Affirmative \\
\hline GD1-C & $\begin{array}{l}\text { Yes, because I can communicate more easily, express myself more } \\
\text { freely. }\end{array}$ & Affirmative \\
\hline GD1-D & Yes, because it is a common language to everyone on the earth. & Affirmative \\
\hline GD2-A & $\begin{array}{l}\text { Yes, because English is the main stream language that used worldwide } \\
\text { for communication. }\end{array}$ & Affirmative \\
\hline GD2-B & $\begin{array}{l}\text { I am not sure, because my English proficiency is not very good; I am } \\
\text { shy to speak to them. }\end{array}$ & Negative \\
\hline GD2-C & Yes, I can communicate with them more confidently. & Affirmative \\
\hline GD2-D & Yes, because they can understand what I want to say. & Affirmative \\
\hline GD3-A & Yes, because English is the international language. & Affirmative \\
\hline GD3-B & $\begin{array}{l}\text { Not quite, you still need academic or professional knowledge, so that } \\
\text { you can socialize with them freely. }\end{array}$ & Negative \\
\hline GD3-C & Yes, I can make friend with them more easily. & Affirmative \\
\hline GD3-D & $\begin{array}{l}\text { Yes, because it is the common language that many people use to } \\
\text { communicate with each others. }\end{array}$ & Affirmative \\
\hline
\end{tabular}

From the above feedback, it is evident that $83 \%$ of the students agreed that learning English will enable them to participate more freely with other cultural groups. The remaining $17 \%$ of the students disagreed, because some of them are shy and do not have the specific knowledge. 
Table 8. Q7: Do you think learning English will earn you a better job in the future? Why? (Instrumental)

\begin{tabular}{|c|c|c|}
\hline No. & Responses of Participants & Instrumental \\
\hline GD1-A & Yes, I can have more opportunity to work in international company. & Affirmative \\
\hline GD1-B & $\begin{array}{l}\text { Yes, we need English to communicate with different kind of customers } \\
\text { that didn't speak our mother tongue. }\end{array}$ & Affirmative \\
\hline GD1-C & Yes, because it is a basic requirement in Malaysia. & Affirmative \\
\hline GD1-D & $\begin{array}{l}\text { Yes, because it is very important. Most company requires you to be able } \\
\text { to read and speak English. }\end{array}$ & Affirmative \\
\hline GD2-A & $\begin{array}{l}\text { Yes, a lot of company conduct interview using English, if we cannot } \\
\text { speak fluently, then we are less competitive. }\end{array}$ & Affirmative \\
\hline GD2-B & $\begin{array}{l}\text { Yes, it is a must in this multi races country; we need English to } \\
\text { communicate to the customer. }\end{array}$ & Affirmative \\
\hline GD2-C & $\begin{array}{l}\text { Yes, you will have advantages compare to those who didn't know } \\
\text { English, more choice, more opportunity. }\end{array}$ & Affirmative \\
\hline GD2-D & $\begin{array}{l}\text { Yes, because if we know English, we can work in an international } \\
\text { company. }\end{array}$ & Affirmative \\
\hline GD3-A & $\begin{array}{l}\text { Maybe, because not all company need people that know English. Got } \\
\text { many big companies in China too, Chinese also very important. }\end{array}$ & Negative \\
\hline GD3-B & Yes, because you chances of being hired is higher. & Affirmative \\
\hline GD3-C & Yes, It is a must in Malaysia. & Affirmative \\
\hline GD3-D & $\begin{array}{l}\text { Yes, because it will be difficult to find quality job, if we do not know } \\
\text { English. }\end{array}$ & Affirmative \\
\hline
\end{tabular}

Based on Table 8, approximately $92 \%$ of the students agreed that learning English will earn them a better job in the future, such as working in an international company, get through the interview and etcetera. Only $8 \%$ of the students disagreed, because they think not all companies require English as Chinese is also important too.

Table 9. Q8: Do you learn English so that you can understand English movies, pop music, novel and etc? Why? (Integrative)

\begin{tabular}{|c|c|c|}
\hline No. & Responses of Participants & Integrative \\
\hline GD1-A & Yes, reading English is my daily habit. & Affirmative \\
\hline GD1-B & Yes, because I like watching English movie, it is the best! & Affirmative \\
\hline GD1-C & $\begin{array}{l}\text { Yes, actually I learn English from watching English movies and } \\
\text { listening English songs. }\end{array}$ & Affirmative \\
\hline GD1-D & $\begin{array}{l}\text { No, because movie have Chinese subtitle, lyrics also got translation } \\
\text { version. }\end{array}$ & Negative \\
\hline GD2-A & Yes, I like English movie and songs. & Affirmative \\
\hline GD2-B & No, because I have no interest in English movies or novel. & Negative \\
\hline GD2-C & $\begin{array}{l}\text { No, I normally look at the subtitle, listen to the melody only. I never } \\
\text { read English novel before, because not my habit. }\end{array}$ & Negative \\
\hline GD2-D & $\begin{array}{l}\text { Yes, because I really want to understand what they said in the movies or } \\
\text { the novel. }\end{array}$ & Affirmative \\
\hline GD3-A & $\begin{array}{l}\text { Yes, I do, because English movies are very interesting. They have the } \\
\text { coolest visual effect. }\end{array}$ & Affirmative \\
\hline GD3-B & $\begin{array}{l}\text { No, I learn English because it is a school subject. Just enjoy the action } \\
\text { in the movie and if I don't understand, I can look at the subtitle. I love }\end{array}$ & Negative \\
\hline
\end{tabular}




\section{Chinese song more than English one.}

No, it is the other way around. I learn English from watching movies or songs, although sometime I don't really understand what it meant, will Negative look up the dictionary then.

GD3-D Yes, in that way I can fully enjoy the movies or novel.

Affirmative

Approximately 58\% of the students agreed that they learn English so that they can understand English movies, pop music and etc. Most of them like English movies and songs; they learn English because they would like to understand more. As for the others, $42 \%$ of the students disagreed, because they either have no interest or they can read the Chinese subtitles or depend on translation for the movies and songs.

Table 10. Q9: Do you read English texts like newspapers, novel and magazine, other than English text book? Why (Instrumental)

\begin{tabular}{|c|c|c|}
\hline No. & Responses of Participants & Instrumental \\
\hline GD1-A & $\begin{array}{l}\text { Yes, I'm trying to learn the grammar and vocabulary in the newspaper } \\
\text { and novel, so that I can improve my English. }\end{array}$ & Affirmative \\
\hline GD1-B & Yes, I read comics, but also can learn some vocabulary. & Affirmative \\
\hline GD1-C & $\begin{array}{l}\text { Yes, I read some novel, because it can help to improve my English } \\
\text { writing skill. }\end{array}$ & Affirmative \\
\hline GD1-D & No, I don’t like reading English, it is difficult to understand. & Negative \\
\hline GD2-A & Yes, because I love English, I speak English at home too. & Affirmative \\
\hline GD2-B & $\begin{array}{l}\text { No, too many English words that I don't know, it will be difficult for } \\
\text { me to read them all. }\end{array}$ & Negative \\
\hline GD2-C & $\begin{array}{l}\text { No, I have so much homework to do; I don't have the time to look up } \\
\text { all the vocabulary in the dictionary. }\end{array}$ & Negative \\
\hline GD2-D & $\begin{array}{l}\text { Yes, I like reading English fiction novel, it also improve my reading and } \\
\text { writing skills. }\end{array}$ & Affirmative \\
\hline GD3-A & $\begin{array}{l}\text { Yes, I do read a lot of newspaper or magazine, so that I can get high } \\
\text { score in the examination. }\end{array}$ & Affirmative \\
\hline GD3-B & No, because my English is no good. & Negative \\
\hline GD3-C & $\begin{array}{l}\text { No, it is too hard for me to understand, so many words that I don't } \\
\text { know. }\end{array}$ & Negative \\
\hline GD3-D & No, because I don't like reading, I prefer watching movies or youtube. & Negative \\
\hline
\end{tabular}

From the above feedback, it is clear that $50 \%$ of the students read English texts other than their English text book, for the sake of hobby and some to improve their reading, writing skills or achieve certain goals. Meanwhile the other $50 \%$ do not read, because they admit that since their English is not good, it would be an extra burden for them to read so many English texts, plus they have no interest in it.

Table 11. Q10: Do you learn English just for your own interest and determine to achieve maximum proficiency? Why? (Integrative)

\begin{tabular}{lll}
\hline No. & Responses of Participants & Integrative \\
\hline GD1-A & No, I learn English because it is very important. & Negative \\
GD1-B & No, is because of study. & Negative \\
GD1-C & No, because it is the basic requirement in most of the University. & Negative \\
GD1-D & No, I learn English so that I can pass the subject. & Negative \\
\hline
\end{tabular}




\begin{tabular}{lll}
\hline GD2-A & Yes, it is a beautiful language, I like it. & Affirmative \\
GD2-B & No, I learn it so that I can get a better job in the future. & Negative \\
GD2-C & No, I am not really interested in English. & Negative \\
GD2-D & Yes, because I enjoy learning English, it is quite interesting to me. & Affirmative \\
GD3-A & Yes, because English make me feel more confident. & Affirmative \\
GD3-B & No, I learn it because in the future we will need it for job interview. & Negative \\
GD3-C & $\begin{array}{l}\text { No, it is important for my study, I may not graduate if I fail the subject. } \\
\text { No, because it is the international language, we have to learn it for a } \\
\text { better future. }\end{array}$ & Negative \\
GD3-D & Negative \\
\hline
\end{tabular}

Table 11 reflect that only $25 \%$ of the students learn English for their own interest and are committed to achieve maximum proficiency. Meanwhile most of the others, which comprise of $75 \%$ of the students learn English because they have to and know that it is important for their studies and future endeavours.

With reference to the above results, it was discovered that in relation to the general question, $83 \%$ of the students are instrumentally motivated to learn English and the remaining 17\% are integratively motivated. As for Q1, 3, 5, 7,9 , which consists of instrumental items, there were forty-three (43) affirmation responses and seventeen (17) negations (71.66\% agree / 28.33\% disagree). While for Q2, 4, 6, 8, 10 which are integrative items, there were twenty-eight (28) affirmation and thirty-two (32) negations (47\% agree / 53\% disagree). From these findings, it is clear that instrumental motivation seems to have more influence/impact on the students than integrative motivation. Thus, we can claim that instrumental motivation promotes better in relation to students' English language learning process.

4.2.2 Challenges Faced by Students towards Learning ESL

The following question investigated the challenges or the area of problem that were encountered by the students during their learning process of English language. What are the factors that affect their motivation towards English language learning?

Table 12. Q11: What are your problems (ex.writing, speaking, grammar, etc) or challenges that will affect your motivation toward English language learning? Why?

\begin{tabular}{|c|c|c|}
\hline No. & Responses of Participants & Challenges \\
\hline GD1-A & $\begin{array}{l}\text { Speaking, because I speak Mandarin in school and home, less } \\
\text { opportunity to practice. }\end{array}$ & Speaking \\
\hline GD1-B & $\begin{array}{l}\text { Grammar and writing essay, I sometime forget the formula and } \\
\text { vocabulary not enough. }\end{array}$ & $\begin{array}{l}\text { Grammar / Writing / } \\
\text { Vocabulary }\end{array}$ \\
\hline GD1-C & $\begin{array}{l}\text { Communicate with people; It makes me shy, because my English is } \\
\text { weak. }\end{array}$ & Speaking \\
\hline GD1-D & Grammar and vocabulary, do not understand. & Grammar / Vocabulary \\
\hline GD2-A & $\begin{array}{l}\text { Well, I can still improve on my vocabulary. I think it is not enough } \\
\text { because there is still difficult word that I don't know. }\end{array}$ & Vocabulary \\
\hline GD2-B & $\begin{array}{l}\text { Writing essay is the problem, because I don't know how to write a good } \\
\text { essay, I don't know many words. }\end{array}$ & Writing / Vocabulary \\
\hline GD2-C & $\begin{array}{l}\text { Grammar of English is very complicated; I can't remember all the rules. } \\
\text { Many words I also don't know the meaning. }\end{array}$ & Grammar / Vocabulary \\
\hline GD2-D & $\begin{array}{l}\text { Speaking and grammar, I do not have much chances to speak to the } \\
\text { foreigner, most of my classmate speak mandarin. }\end{array}$ & Speaking / Grammar \\
\hline GD3-A & $\begin{array}{l}\text { Communication with stranger that speak English, because I seldom } \\
\text { speak to foreigner, worry they don't understand me. }\end{array}$ & Speaking \\
\hline GD3-B & It will be writing, I have to translate word by word in my mind. I & Writing / Grammar \\
\hline
\end{tabular}


always get wrong at the grammar, especially tenses.

$\begin{array}{lll}\text { GD3-C } & \begin{array}{l}\text { Speaking and writing, because I cannot find the word that I want to say } \\ \text { or express. }\end{array} & \begin{array}{l}\text { Speaking / Writing } \\ \text { Vocabulary }\end{array} \\ \text { GD3-D } & \begin{array}{l}\text { It would be grammar and vocabulary, because grammar is boring and I } \\ \text { don't read a lot. }\end{array} & \begin{array}{l}\text { Grammar / Vocabulary } \\ \text { G }\end{array}\end{array}$

From the above feedback, four areas of challenges were mentioned by the students, which are Speaking, Essay writing, Grammar and Vocabulary. Among these challenges, vocabulary was being mentioned the most; followed by grammar, speaking and essay writing.

The findings highlight that majority of the students were motivated towards English language learning, but the level of motivation differs. Instrumental motivation seems to have more impact on the students than integrative motivation. Thus, this study highlights that instrumental motivation promotes students more in their English language learning process. Another highlight is that lack of vocabulary is the main challenge that most students encountered.

\section{Discussion}

The main focus of this study was to investigate ESL students' instrumental and integrative motivation towards English language learning. The analysis of the data collected from students' focus group discussions had provided the researcher with a clearer picture regarding the type of motivation that promotes the learning process the most, as well as challenges faced by the ESL students. This case study has created a guideline to alert the researcher that there is a need to increase the interest of students towards English language learning, so that they can be more integrative motivated and learn the language more effectively with a proactive attitude. Furthermore, provide the students with adequate resources and good learning environments or platform, in order for them to learn the language more effectively.

\subsection{Students' Motivation Level}

This case study indicates that students are more instrumentally motivated than integratively motivated in the learning process of ESL. This finding corroborates with Wong's (2011) study where majority of Chinese students only learn the language for utilitarian purposes. Most of the them learn English with the following motivation; passing the exam, getting a better job in the future, knowing English is important to their success and achievements. Warden and Lin (2000) also suggested that students are generally instrumentally motivated when comes to learning a second language. This can be verified from the high responses from Q1 (100\%), Q3 (75\%) and Q7 (92), which are instrumental items.

However, the data also shows that these instrumentally motivated students do not commit much to their English language learning. This can be perceived from the responses based on Q9 $(50 \%)$ and Q10 $(25 \%)$, which is quite low and not satisfactory. This means that these students are aware that English is important to them; they have to learn it but do not put much time and effort to practice and master it. This result is in line with the findings of Zhigang Wang (1993), instrumentally motivated students cannot commit their time and energy to their learning compared to integratively motivated students. On the other hand, those integratively motivated students, such as GD2-A and GD2-D are willing to read and learn after English classes and beyond their text book, in order to achieve maximum proficiency of the targeted language. This can be verified by the findings of Burcu \& Carol (2012), where they discovered that students' main motivation for studying English was mostly instrumental. However, it was integrative motivation that proves to be the most strongly correlated with successful test results of ESL learning.

Furthermore, the responses from Q2 (30\%) and Q4 (30\%) showed that most of the students do not have specific inspiration or enthusiasm towards English speaking people. They have no interest in the English culture or history and think that English literature is boring and difficult to learn or understand. Morgan \& Wagner (2013) stated that students are less motivated to read because they are forced to and unhappy with the way they are being taught to learn. Moreover, these students have limited opportunities to communicate with the target native group or foreigner. They do not need English language for daily interaction and conversation purposes, which might be the reason why students have difficulty to learn English through integrative motivation. As such, instrumental motivation promotes students more in their English language learning.

\subsection{Challenges Encountered}

The data from Q11 indicated that the challenges confronted by students in their ESL learning process specifically 
were vocabulary and grammar. Most of the students do not have sufficient vocabulary to allow them to read, write and speak fluently. Some of them pointed out that English grammar was difficult to learn, the rules were too complicated to them and it was not easy to remember. This is in line with the findings of Peyyala (2013), where he claimed that the major problem faced by ESL students is unfamiliar vocabulary and they do not understand the text they read. Another challenge is grammar where students find it difficult when the syntax is too complex. Liu and Jackson (2008) also obtained the same results in their research where the lack of vocabulary was regarded as a main obstacle for Chinese English learners. This is because they are not integratively motivated to read and learn beyond English classes, so their vocabulary is poor and they are not familiar with the structure of sentences or how it is normally being applied. If one cannot master grammar and have sufficient vocabulary, they might face difficulties in speaking and writing. Gan (2012) confirmed the above point of view in his research that vocabulary and grammar were the major reasons why students are not able to express themselves clearly and appropriately.

If these challenges are not addressed, it will lower the confidence of students towards English language mastery, which will eventually make them lose interest or unmotivated in ESL learning. As such, the content selected for the students should be suitable for their level, including themes that suit their interest (2015). The teaching method or approaches used in the classroom should increase the involvement of students and also cultivate an effective learning environment, so that students will have more opportunities to speak English (2010).

\section{Conclusion}

This case study has gained pertinent insights on the information regarding the type and level of motivation that influence students the most. The discussions highlight that majority of the students are instrumentally motivated, yet lack commitment in mastering the language. There is a need to motivate the students more integratively, so that they will learn the language with proactive attitudes, continue learning during after school English classes and enjoy the learning process by not seeing it as an extra burden to their study. It is recommended that the teachers should select English literature texts or topics that arouse students' interests and improve their vocabulary and grammar respectively. This case study has its limitations, because only twelve (12) students were involved. The students came from a particular class of a private Chinese school in Penang, hence the findings of this research may not be completely generalised. Furthermore, only one method was utilised in this research with a small sample size to gauge students' perspectives. Therefore, the findings of this case study can be further followed up by a research using a larger sample size and include different types of participants from various other locations.

\section{References}

Ali, O. E. (2009). Second language learning success and motivation. Kafkas University, Turkey. Social behavior and personality, 37(8), 1035-1042. https://doi.org/10.2224/sbp.2009.37.8.1035

Angelica, S. P. (2011). Attitude, motivation and English language learning in a Mexican college context. The University of Arizona. Retrieved from http://hdl.handle.net/10150/145743

Atkinson, J. W., \& Raynor, J. O. (1974). Motivation and achievement. Washington, DC: Winston.

Ausubel, D. A. (1968). Educational Psychology: A Cognitive View. New York: Holt, Rinehart \& Winston. https://doi.org/10.1037/h0025943

Brown, H. D. (1994). Principles of language learning and teaching (3rd ed.). New Jersey: Prentice Hall.

Burcu, O., \& Carol, G.s (2012). Second language motivation. Procedia-Social and Behavioral Science, 70, 1109-1114.

Chunmei, L., Zhu, M., \& Liping, C. (2013). The Study of Student Motivation on English Learning in Junior Middle School - A Case Study of No.5 Middle School in Gejiu. English Language Teaching, 6(9).

Covington. (1998). Intrinsic versus extrinsic motivation in school: A reconciliation. University of California at Berkeley, 9(1).

David, C. (2003). English as a global language. Cambridge, United Kingdom: Cambridge university press.

Deci, E. L., \& Ryan, R. M. (1985). Intrinsic motivation and self-determination in human behaviour. New York: Plenum. https://doi.org/10.1007/978-1-4899-2271-7

Degang, M. (2010). Motivation toward English language learning of the second year undergraduate Thai students majoring in Business English at an English-medium university. Master's project M.A. (Business English for International Communication). Bangkok: Graduate School, Srinakharinwirot University. 
Dornyei, Z. (1994). Motivation and Motivating in the Foreign Language Classroom. The Modern Language Journal, 78(3), 273-284. https://doi.org/10.2307/330107

Dornyei, Z. (2001). Teaching and Researching Motivation. UK, Harlow: Pearson Education. 2001 Motivational strategies in the language classroom. Cambridge: Cambridge University Press. 1994 Motivation and motivating in the foreign language classroom. Modern Language Journal, 78, 273-284. https://doi.org/10.2307/330107

Dornyei, Z. (2001).Teaching and Researching Motivation. Harlow: Pearson Education.

Dornyei, Z. (2002). Motivational strategies in the language classroom. Cambridge: University Press.

Ely, C. M. (1986). Language Learning Motivation: A Descriptive and Causal Analysis. The Modern Language Journal, 70(1), 28-35. https://doi.org/10.1111/j.1540-4781.1986.tb05240.x

Gan, Z. D. (2012). Understanding L2 Speaking problems: Implication for ESL curriculum development in a teacher training institution in Hong Kong. Australian Journal of Teacher Education, 37(1). https://doi.org/10.14221/ajte.2012v37n1.4

Gardner, R. C., \& Lambert, W. E. (1972). Attitude and Motivation in Second Language Learning. Rowley, Massachusetts: Newbury House.

Gardner, R. C. (1983). Learning another language: A true social psychological experiment. Language and Social Psychology, 219-240. https://doi.org/10.1177/0261927X8300200209

Gardner, R. C. (1985) Social psychology and second language learning: The role of attitudes and motivation. London: Edward Arnold.

Gardner, R. C. (2010). Motivation and second language acquisition. The socio educational model. New York: Peter Lang Publishing, Inc.

Harmer, J. (1991). The practice of English language teaching. London: Longman.

Howard, E. K. (2008). How are NASA engineers motivated? An analysis of factors that influence NASA goddard engineers' level of motivation. US

Huitt, W. (2001). Motivation to learn: An overview. Educational Psychology Interactive. Valdosta, GA: Valdosta State University. Retrieved from http://chiron.valdosta.edu/whuitt/col/motivation/motivate.html

Juan, B., \& Jing, S. (2010). English grammatical problems of Chinese undergraduate students. Foreign language department, Liaoning Technical University.

Kea, H. (2008). How Are NASA Engineers Motivated? An Analysis of Factors that Influence NASA Goddard Engineers'Level of Motivation. Retrieved from https://etd.ohiolink.edu/

Kleinginna, P., Jr., \& Kleinginna A. (1981). A categorized list of motivation definitions, with suggestions for a consensual definition. Motivation and Emotion, 5, 263-291. https://doi.org/10.1007/BF00992553

Krashen, S. (1988). Second language acquisition and second language learning. London: Prentice Hall International (UK).

Lei, Z. (2012). Investigation into motivation types and influences on motivation: The case of Chinese non-English major. English Language Teaching, 5(3).

Liu, M., \& Jackson, J., (2008). An exploration of Chinese EFL learners' unwillingness to communicate and $\begin{array}{lllll}\text { foreign language anxiety. Modern Language Journal, 92, } & \text { 71-86. }\end{array}$ https://doi.org/10.1111/j.1540-4781.2008.00687.x

Leigh, E. (2015). Combining young adult and classic literature in a secondary English classroom. St. Marry's college of Maryland.

Marshall, C., \& Rossman, G. B. (2010). Designing qualitative research. Thousand Oaks, Calif: Sage Publications.

Masgoret, A., \& Gardner, R. C. (2003). Attitudes, motivation, and second language learning: A meta-analysis of studies conducted by Gardner and associates. Language Learning, 53(1), 123-163. https://doi.org/10.1111/1467-9922.00212

Melendy, G. (2008). Motivating writers: The power of choice. The Asian EFL Journal, 10(3), 187-198.

Morgan, D. N., \& Wagner, C. W. (2013). What's the catch?: Providing reading choice in a high school classroom. Journal of Adolescent \& Adult Literacy, 56(8), 659-667. https://doi.org/10.1002/JAAL.193 
Muneera, M., \& Shameem, R. G. (2013). Language learning motivation among Malaysian Pre-University students. English Language Teaching, 6(3).

Nakhon, K., \& Tantip, K. (2012). Motivation toward English language learning of Thai student. Majoring in English at Asia-Pacific International University, 7(1), 0905-6931

Oxford, R, \& Shearin, J. (1994). Language Learning Motivation: Expanding the Theoretical Framework. The Modern Language Journal, 78(1), 12-28. https://doi.org/10.1111/j.1540-4781.1994.tb02011.x

Peyyala, R. K. (2013). A critical study on the problems of ESL students. International journal of innovative technology and research, 1(1), 028-031.

Pintrich, P., \& Schunk, D. (1996). Motivation in education. New Jersey, USA: Prentice Hall.

Ratanawalee, W. (2012). A Survey Study of Motivation in English Language Learning of First Year Undergraduate Students at Sirindhorn International Institute of Technology (SIIT), Thammasat University. Thailand: SIIT.

Saran, K. G. (2005). Language policy in Malaysia: Reversing direction. Springer Link, 4(3), 241-260.

Saville-Troike, M. (2006). Introducing second language acquisition. New York: Cambridge University Press.

Seidel, J. (1998). Qualitative Data Analyisis. The Ethnograph v5 Manual, Appendix E. Retrieved from http://www.qualisresearch.com

Taylor, C., \& Gibbs, G. R. (2010). "What is Qualitative Data Analysis (QDA)?", Online QDA Web Site, retrieved from http://onlineqda.hud.ac.uk/Intro_QDA/what_is_qda.php

Thang, S. M. (2004). Learning English in multicultural Malaysia: Are learners motivated? Journal of Language and Learning, 2(2).

Wang, F. (2008). Motivation and English achievement: An exploratory and confirmatory factor analysis of a new measurement for Chinese students of English learning. North American Journal of Psychology, 10(3), 633-646.

Wan-er, Z. (2008). Motivation and language learning in the context of China. Sino-US English Teaching, 5(4). (serial no. 52).

Warden, C. A. S., \& Lin, H. J. (2000). Existence of integrative motivation in an Asian EFL setting. Foreign Language Annals, 33, 535-547. https://doi.org/10.1111/j.1944-9720.2000.tb01997.x

Weiner, B. (1994). Integrating social and personal theories of achievement striving. Rev. Educ. Res. 64, 557-573. https://doi.org/10.3102/00346543064004557

Williams, M., \& Burden, R. L. (1997). Psychology for Language Teachers. Cambridge: Cambridge University Press. https://doi.org/10.1177/0261927X970163001

Wong, Y. M. (2011). A study of instrumental and integrative motivations as factors influencing UTAR third-year Chinese undergraduates in learning ESL. Faculty of arts and social science, University Tunku Abdul Rahman.

Yin, R., (1994). Case study research: Design and methods (2nd ed.). Beverly Hills, CA: Sage Publishing.

Zaidah, Z. (2007). Case study as a research method. Faculty of Management and Human resources department, University Technology Malaysia. Jurnal Kemanusiaan bil9, Jun 2007.

Zhigang, W. (1993). Factors that affect Chinese EFL learner's acquisition. Tianjin Institute of Technology, China.

\section{Copyrights}

Copyright for this article is retained by the author(s), with first publication rights granted to the journal.

This is an open-access article distributed under the terms and conditions of the Creative Commons Attribution license (http://creativecommons.org/licenses/by/4.0/). 